\title{
Distinct positions underpin ecosystem services for poverty alleviation
}

\author{
Caroline Howe, Esteve Corbera, Bhaskar Vira \\ Daniel Brockington and William M. Adams
}

\begin{abstract}
As the concept of ecosystem services is applied more widely in conservation, its users will encounter the issue of poverty alleviation. Policy initiatives involving ecosystem services are often marked by their use of win-win narratives that conceal the trade-offs they must entail. Modelling this paper on an earlier essay about conservation and poverty, we explore the different views that underlie apparent agreement. We identify five positions that reflect different mixes of concern for ecosystem condition, poverty and economic growth, and we suggest that acknowledging these helps to uncover the subjacent goals of policy interventions and the trade-offs they involve in practice. Recognizing their existence and foundations can ultimately support the emergence of more legitimate and robust policies.
\end{abstract}

Keywords Biodiversity conservation, ecosystem services, policy, poverty, trade-offs

\section{Introduction}

Research, policy and new initiatives in conservation are increasingly using the language of ecosystem services. As these schemes expand, and particularly as they spread across the biodiverse tropics and global South, they will come up against problems of poverty alleviation. These encounters will expose conservationists to policies that seek to combine both the conservation of ecosystem services and the alleviation of poverty. Such policies can deny potential conflicts in their objectives and may be based on fundamentally different goals.

This paper attempts to clarify the confusion in policies that neglect trade-offs between competing goals relating to

\footnotetext{
Caroline Howe ${ }^{*}$ (Corresponding author) and Daniel Brockington Sheffield Institute for International Development, University of Sheffield, Sheffield, UK E-mail c.howe.01@cantab.net

Esteve CoRbera Institute of Environmental Science and Technology, Universitat Autònoma de Barcelona, Bellaterra, Spain

Bhaskar Vira and William M. Adams Department of Geography, University of Cambridge, Cambridge, UK

${ }^{*}$ Also at: Centre for Environmental Policy, Imperial College London, London, UK

Received 12 August 2017. Revision requested 17 November 2017.

Accepted 1 February 2018. First published online 30 April 2018.
}

conservation and poverty alleviation. It is modelled on a paper published in 2004 that analysed fractious debates about conservation policy and poverty reduction (Adams et al., 2004). The authors of that paper identified four distinct positions taken by those who were writing and thinking about the relations between conservation and poverty alleviation. These positions were:

(1) The view that conservation and poverty are separate policy realms and should be addressed separately;

(2) The view that poverty matters to conservation because it constrains success;

(3) The view that where poverty alleviation and conservation clash, poverty alleviation should take priority; and,

(4) The view that resource conservation is important whereas other dimensions of conservation (e.g. species conservation) are not.

In pointing out these distinctions Adams et al., sought to categorize types of arguments visible in the discursive landscape, not necessarily associating each position with specific individuals. It offered a heuristic device, holding up a mirror to divided constituencies to point out more clearly the intellectual fault lines that ran through their disputes.

Here, we take the same approach. We identify different positions in work on poverty alleviation and ecosystem services that occur on gradients of concern for poverty, economic growth and environmental health. However, we do not seek to assign them to particular people or organizations. We are, again, identifying arguments, not social groups or epistemic communities. The same person may hold different positions in different circumstances, as we will illustrate below.

The evolving debates about ecosystem services, poverty alleviation and conservation have similarities and differences to the poverty and conservation debates a decade ago, and require a new mirror. The main similarity is that policy initiatives involving ecosystem services are notable for the uniformity of the win-win rhetoric within which they are framed (i.e. that it is possible both to alleviate poverty and enjoy healthy ecosystems at the same time), as was the discourse about conservation and poverty in the 2000 . The difference between the debates then and the debates now is that win-win rhetoric was widely rejected by critics of conservation's social impact in a way that is not happening within current debates. Policy initiatives use the concept 
of ecosystem services to provide a common language to talk about conservation and development goals, in the process masking divergent ideologies and priorities with respect to ecosystem management and development planning. Part of the present task is to make more visible the hard choices that are currently hidden.

Two current examples reflect how complexities are masked behind a win-win rhetoric: the proposed Southern Agricultural Growth Corridor of Tanzania (SAGCOT) and the United Nations Environment Programme's Green Economy Initiative (UNEP, 2016). SAGCOT is an agricultural partnership launched in 2011 to improve agricultural productivity, food security and livelihoods, which seeks also to enhance conservation activities along a broad corridor in southern Tanzania. Supporting documents note that ecosystems (especially forests) provide 'key ecosystem services to support the health of the country's people and the productivity of its enterprises' (SAGCOT, 2016; p. C-4), but do not specify how these relationships work. Thus although forests and protected areas are seen to maintain stocks of terrestrial carbon, it is not clear how either impinges on local poverty. It is suggested new management approaches will 'fairly distribute the benefits generated from ecosystems and their services at various scales' (ibid.), but we do not learn how this will be done, or with what benefits, or for whom (SAGCOT, 2016). In the same way, UNEP's scoping study for the small island state of Saint Lucia also frames a win-win opportunity: it proposes that 'a green economy transition' would provide 'a unique opportunity to promote prolonged economic growth, boost employment and protect the environment' (p. 13) and emphasizes that 'critical ecosystems... can serve to boost conservation efforts while enhancing the sustainable use of local materials for social and economic activities' (p. 14). These statements assume that the priorities informing these different objectives are mutually compatible when, in fact, sustained economic growth on the island may lead to a range of ecological impacts with negative implications for ecosystem functions and services.

It is recognized in the academic literature that the actual pathways between managing ecosystems services to achieve conservation outcomes as well as poverty alleviation are more complex than this win-win rhetoric allows (Naeem et al., 2009; Suich et al., 2015). Win-win outcomes are obtainable (Howe et al., 2014), but by no means straightforward (Muradian et al., 2013). The assumption that ecosystem services provision and poverty alleviation goals can be achieved at the same time fails to acknowledge the existence of incompatibilities that limit the possibility of synergies (Adams, 2014). These research insights are not well recognized in the conservation policy world, where win-win framings persist. A significant difference between debates now and those of the early 2000 s is the nature of policy debate about these trade-offs. In the 2000 s there was heated and visible debate between those advocating (in research literature and policy documents) conservation claims of win-win poverty/conservation outcomes and those criticizing conservation's social impacts (Adams et al., 2004; Roe et al., 2012). Then researchers were divided, now they are more united under a win-win framing that has emerged from the ecosystem services paradigm, and that submerges debate about trade-offs between development and environmental conservation goals.

Yet there is an extensive literature on conflict, trade-off and difference relevant to the relationship between ecosystem services and poverty alleviation. Examples include work on integrated landscape approaches (Sayer et al, 2013; Reed et al, 2017), trade-offs (McShane et al., 2011) and the work of the Poverty and Conservation Learning Group (Poverty and Conservation, 2018). This research provides a further imperative for this paper: unless differences that we highlight below are explicitly recognized then the learning on how to reconcile and work with such divergence may be overlooked.

In what follows we present five normative positions that we believe structure debates with respect to both ecosystem services, conservation and poverty. Similar contributions have been made on the basis of interviews with scientists working on ecosystem services (Hermelingmeier \& Nicholas, 2017). Our approach is different because we are concerned with how poverty alleviation and ecosystem services intersect and how both will influence conservation. As was the case for Adams et al. (2004), these positions have been derived from a mixture of our reviews of the literature (e.g. Howe et al., 2014), and engagement with diverse practitioners and elements of the research community.

\section{Distinct positions}

The five normative positions introduced below reflect different mixes of concern for ecosystem condition, conservation, poverty and economic growth. They differ in the extent to which they accept transformations of nature, their prioritization of poverty reduction and the scale of their ambition. Subsequently, they also diverge in their preferred ecosystem management approaches, the ecosystem services they would be keener to enhance, and the actors in charge of financing, designing and/or brokering policy decisions (Table 1).

The first two positions will be familiar to conservationists reading this journal. The next three positions may appear less distinct. They have to be separated because they entail different paradigms within international development policy and practice about how best to achieve social and economic change, which also have significant implications for the way nature conservation is pursued.

(1) Ecosystems should be managed to deliver services in ways that enable biodiversity conservation.

This position prioritizes conservation goals and the preservation of ecosystem attributes. It emphasizes the intrinsic 
TABLE 1 Normative positions with respect to ecosystem services and poverty alleviation in policy debates and decisions.

\begin{tabular}{|c|c|c|c|}
\hline Position & $\begin{array}{l}\text { Narrative emphasis } \\
\text { \& principles }\end{array}$ & $\begin{array}{l}\text { Preferred ecosystem management } \\
\text { strategy \& policy approaches }\end{array}$ & Principal advocates \\
\hline $\begin{array}{l}\text { (1) Ecosystems should be } \\
\text { managed to deliver services } \\
\text { in ways that facilitate bio- } \\
\text { diversity conservation }\end{array}$ & $\begin{array}{l}\text { The conservation of ecosys- } \\
\text { tems should be prioritized over } \\
\text { poverty concerns; ecosystem } \\
\text { services \& poverty alleviation } \\
\text { policies should be delinked, } \\
\text { treated as separate policy }\end{array}$ & $\begin{array}{l}\text { Ecosystem management should } \\
\text { minimize human interaction with } \\
\text { ecosystems: national \& natural } \\
\text { parks, other types of protected } \\
\text { areas (e.g. biosphere reserves, } \\
\text { conservation easements) }\end{array}$ & $\begin{array}{l}\text { Actors who interpret biodiversity as } \\
\text { species, \& think all species are es- } \\
\text { sential to the survival of ecosys- } \\
\text { tems; others who see a sustainable } \\
\text { industry in nature/wildlife tourism }\end{array}$ \\
\hline
\end{tabular}

(2) Ecosystems should be managed to deliver services in ways that maintain their functional integrity

(3) Ecosystems should be managed to deliver services in ways that protect \& secure the existing lives \& livelihoods of the poor

(4) Ecosystems should be managed to deliver services in ways that bring new benefits to the poor

(5) Ecosystems should be managed to deliver services in ways that maximize economic growth
Poverty alleviation should be prioritized over ecosystem services concerns, but avoiding considerable changes in ecosystem function \& structure

Ambivalent about the relationship between ecosystem services \& poverty alleviation

Poverty alleviation should be prioritized over ecosystem services concerns
Ecosystem management should focus on providing services (provisioning, regulating \& supporting) that sustain the livelihoods of the poor \& buffer them from shocks: ecosystem-based adaptation initiatives, sustainable livelihood approaches

Ecosystem management should prioritize the provision of ecosystem services that can generate new revenue streams, or maximize existing ones, ideally guaranteeing that the poor control \& have access to these services: novel ecosystem management approaches, such as biodiversity or carbon offsetting

Ecosystem management should be geared to provide those services that maximize economic revenue, particularly at national level: intensive \& market-oriented forms of ecosystem management to generate valuable goods, including, for example, industrial agriculture \& forestry
Actors who believe that ecosystem services are essential to human survival, at any scale from local to global, \& who stress that ecosystem services management can produce key benefits to people's livelihoods that could lift them out of poverty

Actors who support resource-based livelihoods \& bottom-up, community-based development approaches

Actors who support innovative forms of resource management that might potentially entail a transformation of existing ecosystem function \& structure

Actors who believe the size of the economy \& per capita GDP are the only useful measure of development value of biodiversity (McCauley, 2006), and typically involves the protection of ecosystems that contain rare or unique biodiversity, usually through protected areas. It is a traditional conservationist position, where such areas are defined as no-go zones for development. It recognizes the general importance of poverty alleviation and the potential importance of ecosystem services for poverty alleviation (Diaz et al., 2018), but treats this as a separate policy realm, to be pursued using separate strategies, often in different places, such as through land sparing interventions (Balmford et al., 2005).

This position allows the possibility of communities living in or around protected areas to earn a living from employment as park guards, wildlife tourism or payments for ecosystem services, often in combination, as, for example, in East Africa, (Sandbrook \& Adams, 2012). These benefits from conservation activity may be shared with poor people and contribute to poverty alleviation. Since the 1980 os 
conservation organizations have increasingly emphasized the potential for community conservation, and many conservation managers now seek to stimulate flows of economic revenues from protected areas for poor people in neighbouring communities (Adams et al., 2004). However, such development aims are, for supporters of this position, incidental to biodiversity conservation goals and the maintenance of key supporting and regulating ecosystem services, while forms of ecosystem management threatening the latter will not be accepted even if they promise poverty alleviation opportunities. For such conservationists, the priority of biodiversity over development remains a powerful normative position informing ecosystem management and the acceptance of trade-offs.

Those who adhere to this strict conservation position would typically include donors, non-governmental organizations (NGOs) and government agencies involved in promoting or managing protected areas, usually aimed at conserving charismatic or endemic species, as well as biologically rich ecosystems. The priority of biodiversity over development remains a powerful normative belief informing ecosystem management.

(2) Ecosystems should be managed to deliver services in ways that maintain their functional integrity.

This position emphasizes functional rather than structural dimensions of ecosystems-how they work rather than their particular composition in terms of biodiversity. It accepts that human welfare depends on functioning ecosystems (to deliver clean water, air and harvests), and therefore also the role of ecosystem functions in relation to poverty alleviation (Juniper, 2013; Diaz et al., 2018). This position supports ecosystem management approaches that can increase local income and support livelihood diversification, such as sustainable agriculture and forest management programmes, ideally integrated within landscape management approaches. However, this position differs from the first in that it accepts some measure of ecosystem transformation, assuming ecosystem function is maintained (e.g. low levels of wildlife or timber harvesting or introduction of exotic species). Under this position, poverty alleviation is accepted as an important policy goal, but the maintenance of ecosystem functions takes priority over poverty alleviation needs (Naeem et al., 2009).

Some conservation organizations base their work on a general case for the importance of areas of natural habitat for human welfare and they show elements of this thinking in their literature. For example, Conservation International describe themselves as 'helping to build a healthier, more prosperous and more productive planet', because 'human beings are totally dependent on nature-and that by saving nature, we're saving ourselves' (Conservation International, 2017).

The prioritization of ecosystem function can be applied at a variety of scales. At the global scale the benefits of carbon sequestration provided by trees and other vegetal biomass could be an argument to preserve forests, although a plantation forest may deliver this service as well (or conceivably better) than an old-growth forest. At the scale of a river catchment, headwater forests or floodplain wetlands (whether natural or managed) may be important to flood control, or clean water delivery downstream. Each of these might produce co-benefits for poor people, but the primary motivation for management interventions in these cases is to maintain ecosystem function rather than to maximize benefits to the poor or to maximize ecosystem biodiversity.

(3) Ecosystems should be managed to deliver services in ways that protect and secure the existing lives and livelihoods of the poor.

This position recognizes the dependence of the poor on ecosystems, and seeks to maintain these flows of benefits (Turner et al., 2012). Poverty alleviation is given a high priority, but within the bounds of a limited degree of environmental transformation. Arguments based on this position propose ecosystem management to maintain supporting and provisioning services that sustain the livelihoods of the poor and buffer them from shocks. This position is reflected in arguments that the livelihoods of the poor depend directly on ecosystem services of various kinds (Turner et al., 2012), and by those who advocate small-scale farming and rural livelihoods to sustain present lifestyles (e.g. Peters, 2013). It is also revealed where it is argued that ecosystem services can protect poor people from shocks that might exceed coping capacity. Such protection might derive directly from physical buffering against natural hazards (e.g. coral reefs; Ferrario et al., 2014), or famine foods from local ecosystems in times of drought or economic catastrophe (Mortimore \& Adams, 1999). The forms of poverty that are identified in this position include those that pertain to insecurity, risk and uncertainty, rather than just increasing income.

With respect to conservation debates, this position has come to the fore in contests surrounding the Forest Rights Act in India (Ramnath, 2008). This legislation legitimized long-standing individual and customary use and occupation of forest areas, which had been deemed illegal as a result of imperfect and incomplete forest settlement processes that had been implemented by both colonial and post-Independence forest administrations in India (Kothari et al., 1989). Forest dwellers have been given rights to continue their existing forest use and access practices, recognizing that accessing such resources reduces poverty and vulnerability to misfortune.

This position supports similar ecosystem management that may look like the outcomes of positions 1 or 2; for example promoting the preservation of habitat. However, management will diverge depending on the relative importance given to preserving biodiversity (position 1) or the needs of the poor, if these are perceived to be in conflict. Trade-offs are obviously possible between the positions. 
Additionally, if there is a choice between, for example, the valuable provisioning services of a prawn farm and the regulating services of mangroves, or between the benefits from grazing in a catchment forest and the water needs of a downstream town, advocates of this position would be inclined to favour options that enhance supporting services and propoor outcomes. They would typically include NGOs with a rural development focus, which advocate for resourcebased livelihoods and community governance structures (Rangan, 2000).

(4) Ecosystems should be managed to deliver services in ways that bring new benefits to the poor.

This position emphasizes the potential of new marketbased instruments to create commodities whose trade can benefit the poor, and particularly address income poverty. It suggests that ecosystems should be managed to enable services such as carbon sequestration, watershed regulation or pollination to be traded or paid for in ways that help finance a pathway out of poverty. Payments for standing forests or increased carbon stocks (REDD+) are examples of such mechanisms, if coupled with arrangements for community control of forest resources and if resulting revenue streams are a means to enable impacts on poverty reduction (Phelps et al., 2012). An example of this is Mexico's investment plans to realize avoided deforestation emissions through conservation payments and sustainable resource management activities in targeted landscapes. The landscape focus resonates with position 2 but is distinctive to the extent it expects to recover such investment through carbon markets and uses revenues for upscaling.

This position places high importance on poverty alleviation, and accepts a relatively high degree of environmental transformation. In conservation circles it can be used to advocate for new forms of community-based natural resource management that devolve power over wildlife or forest resources to local groups and at the same time increase the extent of protected land by allowing those groups to establish community-managed hunting or forest reserves. As some have argued, we need to see such arrangements as a form of payment for ecosystem services (Naidoo et al., 2011; Corbera, 2012), but we also need to recognize they are a distinctive form of poverty alleviation that differ from position 3 in the innovation and entrepreneurship they entail. As a result of this ingenuity, considerable new profit-making opportunities are being developed to benefit local groups (Murphree, 2001). At the same time, as we observed above, this sort of win-win outcome is rare. The scale of change required to rework societies, landscapes and ecosystem management can also cause these schemes to fail with respect to poverty alleviation (Igoe \& Croucher, 2007) and conservation (Scullion et al., 2011) goals. Regardless of the outcome, however, the point is that this position is marked with the ambition of realizing new income streams and new management arrangements to achieve them.

This position can lead to outcomes similar to those from position 1 (i.e. biodiversity conservation through protected or voluntary conserved areas) if new income streams enhance the sustainability of existing natural ecosystems by increasing the value of existing services. However, outcomes will differ from position 1 where ecosystem management involves transformed land management. It shares outcomes with position 2, ecosystem function, although the focus is on the monetization of benefit streams through ecosystem service payments, rather than just maintaining ecosystem integrity. It might also share outcomes with position 3, livelihood security, except that its aim is specifically to create new revenue streams, and therefore it involves a move away from existing, traditional or indigenous ways of life, and particularly a move to market-based transactions over resources. Advocates of this position encompass NGOs and government agencies interested in applying novel ecosystem management approaches and technologies to development solutions within market-based or donor-driven strategies.

(5) Ecosystems should be managed to deliver services in ways that maximize economic growth.

This position follows the standard model of development, which holds that the most effective way to reduce poverty is to maximize economic growth, allowing benefits to trickle down to the poor. It accepts potentially radical transformation of ecosystems to achieve economic development (e.g. the creation of infrastructure such as dams or roads, new mines or intensive agriculture) although good practice will seek to minimize environmental impacts and maintain ecosystem integrity (position 2). Position 5 differs from position 4 because it emphasizes the efficient production of ecosystem goods and services from which benefits can be distributed to the poor, rather than rewarding the direct control or management of those ecosystems and benefits by the poor themselves. Its concern is to make people less poor by moving them out of unproductive areas of the economy, which are predominantly rural, resource-based livelihoods and into more productive areas, predominantly, industrial and service industries (Collier \& Dercon, 2014; Dercon \& Gollin, 2014).

This position may appear to have little merit for conservationists, but its influence is visible in some conservation discussions. Implicit in the land-sparing versus landsharing debate for example is the notion that land which is not conserved will be used as intensively as possible, to maximize provisioning services that can enhance human welfare (Balmford et al., 2005). In this respect positions 1 and 5 can, metaphorically, occupy common ground. Some green development schemes (such as our opening examples from Tanzania and St Lucia) find space for nature because that space can also be profitable. The pursuit of green 
economic growth through establishing profitable tourism destinations would seek to pursue both goals of conservation and economic growth. Similarly, the wastelands and land degradation narrative suggests that where land cannot be used productively because of its remoteness or hostile environments, then it could be conserved profitably. There are also shades of this thinking in the corporate-focused environmental policies that make provision for biodiversity conservation as a means of enhancing profit.

\section{Discussion and conclusion}

We recognize that the positions described here are abstracted. In practice they are often jumbled together in policy documents, websites, and in the minds of policymakers, and those working in donor organizations and NGOs. IUCN, for example, states in a webpage that 'protected areas... are a mainstay of biodiversity conservation, while also contributing to people's livelihoods.... Protected areas are at the core of efforts towards conserving nature and the services it provides us-food, clean water supply, medicines and protection from the impacts of natural disasters' (IUCN, 2017; our emphasis). They are also jumbled within organizations, in the sense that positions can change over time, for example, Conservation International's adoption of ecosystem services and interests such as human health, which we mentioned above, was part of a radical transformation of the image, brand and ethos of the organization (Conservation International, 2017).

That mixing of positions is precisely why we have sought to distinguish them here. The policy rhetoric on ecosystem services and poverty alleviation, with its search for common causes, can serve to erase or obscure fundamental differences in goals or objectives. Failure to acknowledge differences between these positions obscures choices and risks undermining sustainable and just outcomes.

Some of the positions we describe may be more strongly advocated by certain kinds of organizations and actors: thus, biodiversity conservation organizations are likely to emphasize positions 1 and 2, and poverty organizations positions 3 and 4 . Because such groups tend to work in places with different attributes, there can also be a spatial dimension to the adoption of different positions. Thus, highly diverse forests housing critically endangered endemics may suggest position 1; a degraded, species-poor secondary forest managed by the government that is a water catchment for downstream towns may suggest position 2; such a forest held insecurely by smallholders and the focus of an agribusiness land-grab might suggest position 3; if the forest is beautiful and contains remnant rare species it might suggest position 4 (e.g. a community wildlife lodge). If the degraded forest lies over a valuable mineral, a government economist or corporate geologist might see potential in position 5 , accepting destruction of the forest to make way for a mine to yield tax revenues that can be used for development elsewhere.

To some extent spatial solutions, along the lines suggested by integrated landscape approaches (Reed et al., 2016, 2017), may provide a way of resolving differences once they are recognized. However, the same forests can be valued for their contributions to poverty alleviation, or new forms of commodity production. Contests over the role of tourism in the conservation of gorillas provide a classic example (Sandbrook, 2008). Or to put this differently: the positions we describe do not derive from nature, but from the social values through which conservation, development and economic policies are constructed.

In other situations, the different positions may lead to similar outcomes (where, for example, the needs of forest communities, biodiversity protection and ecosystem integrity all demand the maintenance of forest cover). But again this strengthens the need for clarity as to the normative positions underpinning different calls. These positions retain their power to lead stakeholders in different directions. In almost every case where different positions are merged (whether developing carbon trading in inhabited biodiverse forests, or ecotourism within protected areas), there are choices about the degree of ecosystem transformation accepted and the balance of local control, which are often associated with different institutional and management strategies. Acknowledging diverse normative positions will improve decision-making by being more inclusive of the interests of different stakeholder groups and bringing tradeoffs onto the negotiating table.

\section{Acknowledgements}

This work was funded with support from the Ecosystem Services for Poverty Alleviation (ESPA) Programme [NE/ESPA/o10oo1] (Grant number NE/Moo7561/1). The ESPA programme is funded by the UK Department for International Development, the Economic and Social Research Council and the Natural Environment Research Council. We also acknowledge the comments provided by Gretchen Daily, Ben Halpern, Jim Salzman, Sarah Anderson, Mark Buntaine and Richard Norgaard to an earlier version of the normative positions. EC acknowledges the financial support of the UAB-Banco de Santander Talented Researcher Programme and notes that this article contributes to ICTA-UAB 'María de Maeztu Unit of Excellence' (MDM-2015-0552).

\section{Author contributions}

The authors contributed equally to the development of this article. 


\section{References}

Adams, W.M. (2014) The value of valuing nature. Science, 346, 549-551. Adams, W.M., Aveling, R., Brockington, D., Dickson, B., Elliott, J., Hutton, J. et al. (2004) Biodiversity conservation and the eradication of poverty. Science, 306, 1146-1149.

Balmford, A., Green, R.E. \& Scharlemann, J.P.W. (2005) Sparing land for nature: exploring the potential impact of changes in agricultural yield on the area needed for crop production. Global Change Biology, 11, 1594-1605.

Collier, P. and Dercon, S. (2014) African agriculture in 50 years: smallholders in a rapidly changing world? World Development, 63 , 92-101.

Conservation International (2017) Http://www.conservation. org/about [accessed 8 July 2017].

Corbera, E. (2012) Problematizing REDD+ as an experiment in payments for ecosystem services. Current Opinion in Environmental Sustainability, 4, 612-619.

Dercon, S. \& Gollin, S. (2014) Agriculture in African development: theories and strategies. Annual Review of Resource Economics, 6, 471-492.

Diaz, S., Pascual, U., Stenseke, M., Martin-Lopez, B., Watson, R.T., MolnáR, Z. et al. (2018) Assessing nature's contributions to people. Science, 359, 270-272.

Ferrario, F., Beck, M.W., Storiazzi, C.D., Micheli, F., Shephard, C.C. \& Airoldi, L. (2014) The effectiveness of coral reefs for coasta hazard risk reduction and adaptation. Nature Communications, 5 , 3794.

Hermelingmeier, V. \& Nicholas, K.A. (2017) Identifying five different perspectives on the ecosystem services concept using Q methodology. Ecological Economics, 136, 255-265.

Howe, C., Suich, H., Vira, B. \& Mace, G.M. (2014) Creating win-wins from trade-offs? Ecosystem services for human well-being a meta-analysis of ecosystem service trade-offs and synergies in the real world. Global Environmental Change, 2, 263-275.

Igoe, J. \& B. Croucher (2007) Conservation, commerce and communities: the story of community-based wildlife management areas in Tanzania's northern tourist circuit. Conservation and Society, 5, 534-561.

IUCN (2017) Https://www.iucn.org/theme/protected-areas/about [accessed 7 July 2017].

Juniper, T. (2013) What has Nature Ever Done for Us? How Money Really Does Grow on Trees. Profile Books, London, UK.

Kothari, A., Pande, P., Singh, S. \& Variava, D. (1989) Management of National Parks and Sancturies in India. A Status Report. Indian Institute of Public Administration, New Delhi, India.

McCauley, D.J. (2006) Selling out on nature. Nature, 443, 27-28.

McShane, T.O., Hirsch, P.D., Trung, T.C., Songorwa, A.N., Kinzig, A., Monteferri, B. et al. (2011) Hard choices: making trade-offs between biodiversity conservation and human well-being. Biological Conservation, 144, 966-972.

Mortimore, M. \& Adams, W.M. (1999) Working the Sahel: Environment and Society in Northern Nigeria. Routledge, London, UK.

Muradian, R., Arsel, M., Pellegrini, L., Adaman, F., Aguilar, B., Agarwal, B. et al. (2013) Payments for ecosystem services and the fatal attraction of win-win solutions. Conservation Letters, 6, 274-279.

Murphree, M. (2001) Community, council and client. A case study in ecotourism development from Mahenye, Zimbabwe. In African Wildlife and Livelihoods (eds D. Hulme \& M. Murphree), pp. 177194. Heinemann, Portsmouth, UK.

Naeem, S., Bunker, D.E., Hector, A., Loreau, M. \& Perrings, C (2009) Biodiversity, Ecosystem Functioning and Human Wellbeing:
An Ecological and Economic Perspective. Oxford University Press, Oxford, UK.

Naidoo, R., Weaver, C., De Longcamp, M. \& Du Plessis, P. (2011) Namibia's community-based natural resource management programme: an unrecognized payments for ecosystem services scheme. Environmental Conservation, 38, 445-453.

Peters, P.E. (2013) Land appropriation, surplus people and a battle over visions of agrarian futures in Africa. The Journal of Peasant Studies, 40, 537-562.

Phelps, J., Edward, L., Webb, E.L. \& Adams, W.M. (2012) Biodiversity co-benefits of policies to reduce forest-carbon emissions. Nature Climate Change, 2, 497-503.

Poverty and Conservation (2018) The Information Portal of the Poverty and Conservation Learning Group. Http://www. povertyandconservation.info [accessed 9 February 2018].

Ramnath, M. (2008) Surviving the Forest Rights Act: between Scylla and Charybdis. Economic and Political Weekly, March: 37-42.

Rangan, H. (2000) Of Myths and Movements: Rewriting Chipko into Himalayan History. Verso, London, UK.

Reed, J., Van Vianen, J., Deakin, E.L., Barlow, J. \& Sunderland, T. (2016) Integrated landscape approaches to managing social and environmental issues in the tropics: learning from the past to guide the future. Global Change Biology, 22, 2540-2554.

Reed, J., Van Vianen, J., Barlow, J. \& Sunderland, T. (2017) Have integrated landscape approaches reconciled societal and environmental issues in the tropics? Land Use Policy, 63, 481-492.

Roe, D., Elliott, J., Sandbrook, C. \& Walpole, M. (2012) Biodiversity Conservation and Poverty Alleviation: Exploring the Evidence for a Link. Wiley, Chichester, UK.

SAGCOT (2016) The SAGCOT Greenprint: A Green Growth Investment Framework for the Southern Agricultural Growth Corridor of Tanzania. Http://www.sagcot.com/uploads/media/ SAGCOT_Greenprint.pdf [accessed 30 June 2016].

SANDBrooK, C. \& AdAms, W.M. (2012) Accessing the impenetrable: the nature and distribution of tourism benefits at a Ugandan national park. Society and Natural Resources, 25, 915-932.

SANDBRook, C.G. (2008) Putting leakage in its place: the significance of retained tourism revenue in the local context in rural Uganda. Journal of International Development, 22, 124-136.

Sayer, J., Sunderland, T., Ghazoul, J., Pfund, J.-L., Sheil, D., MeijaARD, E. et al. (2013) Ten principles for a landscape approach to reconciling agriculture, conservation, and other competing land uses. Proceedings of the National Academy of Sciences of the United States of America, 110, 8349-8356.

Scullion, J., Thomas, C., Vogt, K., Pérez-Maqueo, O. \& Logsdon, M. (2011) Evaluating the environmental impact of payments for ecosystem services in Coatepec (Mexico) using remote sensing and on-site interviews. Environmental Conservation, 38, 426-434.

Suich, H., Howe, C. \& MACE, G.M. (2015) Ecosystem services and poverty alleviation: a review of the empirical links. Ecosystem Services, 12, 137-147.

Turner, W.R., Brandon, K., Brooks, T.M., Gascon, C., Gibbs, H. K., LAWRENCE, K.S. et al. (2012) Global biodiversity conservation and the alleviation of poverty. Bioscience, 62, 85-92.

UNEP (2016) Green Economy Scoping Study for Saint Lucia. Http:// web.unep.org/greeneconomy/greeneconomy/sites/unep.org. greeneconomy/files/publications/final_green_economy_scoping study_for_saint_lucia.pdf [accessed 9 February 2018].

\section{Biographical sketches}

Caroline Howe works on the relationship between the natural environment and human well-being and how these relationships alter 
over time and space and under land-use and climate change. EsT EVE CORBERA studies human relationships with nature, and the impact of social, policy and environmental change on resource governance. BHASKAR VIRA's research interests centre on the changing political economy of environment and development, especially in South Asia, with a particular interest in the political ecology of forests, water, food, wildlife and land-use change, and the social and political context for biodiversity conservation. DAN BROCKINGTON's research covers the social impacts of conservation, relationships between capitalism and conservation, the work of media and celebrity in development and long-term livelihood change in East Africa. William Adams is interested in the evolution of ideas in conservation and resource development, and what happens when they are applied. 